\title{
PENCAPAIAN STANDAR NASIONAL PELAYANAN KESEHATAN PEDULI REMAJA PADA POSYANDU REMAJA DI SURABAYA
}

The Achievement of National Standard of Teenage Health Care Service at Teenage Integrated Service Post in Surabaya

Fitriani Putri Eka Ningsih

Fakultas Kesehatan Masyarakat, Universitas Airlangga, Indonesia

E-mail: mputjos@gmail.com

\begin{abstract}
Since 2010 Surabaya has teenage integrated service post (posyandu) to solve teenagers' problem, but there were still a lot teenagers' problem in Surabaya include early marriage. This study aims to determine about National Standard achievement of teenagers health care service at integrated service post in Surabaya. This research used cross sectional design with qualitative descriptive approach. The interview was conducted in 15 teenage integrated service post in Surabaya, and the respondent was the coordinator of teenage integrated service post. Result showed that assessment of teenage and networking standard are difficult to achieve. That was related to teenagers' interest and socialization which is not well organized. Also, there was no specific guidelines for teenagers so the officers should guess and make their own guidelines. There were a lot teenage integrated service post in Surabaya did not have completed filing and did not record and report their activities. The lack of health management in teenage integrates service post influence the achievement of PKPR National Standard.
\end{abstract}

Keywords: health care service, integrated service, National standard, teenage

\begin{abstract}
ABSTRAK
Surabaya telah memiliki posyandu remaja sejak 2010 untuk menangani masalah remaja, namun masih terdapat masalah remaja di Surabaya termasuk perkawinan remaja. Penelitian ini bertujuan mempelajari pencapaian standar nasional PKPR pada remaja di Kota Surabaya. Penelitian ini menggunakan rancang bangun cross sectional dengan pendekatan deskriptif kualitatif. Interview melibatkan 15 remaja di kota Surabaya dengan koordinator remaja sebagai responden. Penilaian dilakukan dengan lembar panduan wawancara oleh peneliti dan sinkronisasi dengan data sekunder. Hasil penelitian menunjukkan bahwa tidak semua standar terpenuhi. Standar remaja dan jejaring sangat sulit untuk dipenuhi. Hal ini berhubungan dengan ketertarikan dan sosialisasi yang terselenggara dengan tidak baik. Kesulitan lainnya ditemukan pada tidak adanya petunjuk spesifik bagi remaja jadi petugas harus menebak dan membuat petunjuk bagi mereka sendiri. Banyak remaja tidak memiliki kelengkapan berkas dan tidak melakukan kegiatan pencatatan dan pelaporan kegiatan yang dilakukan. Kekurangan dari manajemen kesehatan di dalam pelayanan remaja memengaruhi hasil dari PKPR standar nasional.
\end{abstract}

Kata Kunci: pelayanan kesehatan, posyandu, remaja, standar Nasional

Received: 10 July 2017

Accepted: 2 August 2017

Published: 01 June 2018

\section{PENDAHULUAN}

Remaja merupakan masa terjadinya tumbuh kembang secara pesat baik fisik, psikologis atau secara intelektual. Masa tumbuh kembang tersebut mengakibatkan para remaja memiliki sifat dan karakter khas yang sama yaitu rasa keingintahuan yang tinggi dan gemar melakukan petualangan serta suka terhadap tantangan. Remaja juga cenderung berani mengambil risiko atas perilaku yang diperbuat tanpa mempertimbangkan secara matang lebih dahulu. Sifat ini dihadapkan pada ketersediaan sarana di sekitarnya yang dapat memenuhi keingintahuan tersebut. Keadaan ini sering mendatangkan konflik batin dalam dirinya ketika tidak mampu untuk dikontrol.

Menurut World Health Organization (WHO) sekitar seperlima dari penduduk dunia adalah remaja berusia 10-19 tahun. Sekitar 900 juta berada di negara berkembang. Di Indonesia pada tahun 2007 jumlah remaja usia 10-24 tahun terdapat sekitar 64 juta atau $28,64 \%$ dari jumlah penduduk Indonesia (Muadz, 2008). Jumlah usia muda Indonesia antara 15-24 tahun diperkirakan kurang lebih 17 persen dari total penduduk. Remaja di kehidupan memiliki peranan penting dalam masa depan Indonesia, mulai dari membangun rumah tangga, menjadi pemimpin dalam pengambilan keputusan, dan menjadi tulang punggung perekonomian nasional Indonesia (SDKI, 2012). Perkawinan usia muda merupakan perkawinan yang dilakukan pada usia remaja yaitu di bawah usia 16 tahun pada wanita dan di bawah usia 19 tahun pada pria. Perkawinan usia muda selain mencerminkan rendahnya status wanita, juga merupakan tradisi sosial yang menopang tingginya angka kesuburan. Masyarakat internasional secara 
konsisten telah mengukuhkan hak-hak remaja akan informasi tentang kesehatan reproduksi remaja (KRR) yang benar dan pelayanan kesehatan reproduksi (KR) termasuk konseling saat International Conference on Population and Development (ICPD) tahun 1994 (Romauli, 2011).

posyandu Remaja memiliki fungsi sebaga wadah, pembinaan dan media komunikasi bagi remaja agar para remaja tidak salah menginterpretasikan perilakunya. Sejauh ini yang dilakukan dalam remaja yaitu pembinaan sebagai upaya promotif serta preventif untuk menghindari perilaku seksual dini. Penyuluhan dan diskusi dilakukan dengan kelompokkelompok kecil di posyandu remaja yang dilakukan secara rutin satu bulan sekali (Dinkes, 2012). Status kesehatan usia remaja sangat penting, terutama kesehatan reproduksi selama kehidupan di masa remaja dan dewasa muda. Berdasarkan hal tersebut maka penting untuk merancang program yang efektif agar remaja berhasil ke masa dewasa. Hal yang diperlukan adalah memahami apa yang menjadi pilihan remaja, hak, dan tanggung jawab sehubungan dengan kesehatan reproduksi remaja (SDKI, 2012).

Kota Surabaya turut menunjukkan aksi kepedulian terhadap remaja melalui remaja. Posyandu remaja di Kota Surabaya telah berdiri sejak 2010, ada 15 dari 62 Puskesmas yang mempunyai program posyandu remaja. Posyandu remaja yang ada bertanggung jawab dalam kaderisasi dan penyusunan program setiap tahunnya, sehingga fungsi dari posyandu remaja dapat berjalan sesuai rencana dan tujuan. Posyandu remaja di Surabaya telah ada hampir 5 tahun, dan tiap posyandu remaja melakukan kaderisasi setiap tahunnya. Program posyandu remaja yang ada telah memiliki standar prosedur operasional untuk diaplikasikan. Meskipun demikian angka perkawinan remaja di Surabaya masih termasuk tinggi di Jawa Timur.

Tujuan dari penelitian ini yaitu untuk mengetahui pencapaian standar Nasional Pelayanan Kesehatan Peduli Remaja (SN-PKPR) pada posyandu remaja di Kota Surabaya. SN-PKPR tersebut terdiri dari standar tenaga kesehatan, standar fasilitas kesehatan, standar remaja, standar jejaring dan standar manajemen kesehatan. Manfaat penelitian ini adalah untuk dapat memberikan wawasan baru di bidang pelayanan kesehatan terutama mengenai pelayanan kesehatan remaja dan pencapaian remaja dalam standar nasional pelayanan kesehatan peduli remaja (PKPR).

\section{METODE}

Jenis penelitian ini merupakan studi deskriptif karena penelitian ini dilakukan tanpa ada intervensi perlakuan pada subyek penelitian. Penelitian ini menggunakan pendekatan cross sectional dimana pengukuran dilaksanakan pada waktu yang bersamaan. Lokasi penelitian ini adalah pada 15 remaja di kota surabaya yang dilaksanakan pada bulan Juli 2016. Populasi pada penelitian ini adalah 15 koordinator posyandu remaja. Setiap diambil koordinator tersebut sebagai responden. Data primer penelitian diperoleh melalui wawancara dengan menggunakan panduan wawancara, sedangkan data sekunder diperoleh berdasarkan lembar catatan dan dokumen yang dimiliki oleh posyandu remaja.

\section{HASIL DAN PEMBAHASAN}

Standar yang digunakan dalam remaja adalah SN-PKPR. Standar tersebut dievaluasi setiap 6 bulan sekali oleh Dinas Kesehatan Kota Surabaya. Penilaian tersebut dilakukan untuk menjamin mutu posyandu remaja di setiap Puskesmas. Berdasarkan target yang sudah ditentukan dari standar yang ada untuk pemenuhan SN-PKPR tersebut, standar pertama yaitu standar tenaga kesehatan. Standar tenaga kesehatan memiliki peranan penting dalam SN-PKPR, dengan ketersediaan tim tenaga kompeten yang memiliki pengetahuan, sikap, serta keterampilan khusus dapat secara maksimal akan mendukung program PKPR sesuai standar Nasional.

Berdasarkan Kemenkes RI (2013) dalam buku pedoman PKPR menyebutkan bahwa standar tenaga kesehatan memiliki beberapa indikator. Indikator tersebut antara lain pengetahuan dan kompetensi petugas serta pelayanan konseling. Variabel standar tenaga kesehatan memiliki skor maksimal 60 poin. Kota Surabaya memiliki 40\% posyandu remaja dengan pencapaian tertinggi dan $60 \%$ dengan pencapaian rendah untuk variabel tenaga kesehatan. Tim tersebut disesuaikan dengan kebutuhan posyandu remaja. Pembagian tugas hanya dilakukan saat penyuluhan sesuai dengan materi yang ada. Pembagian tersebut ditentukan oleh koordinator posyandu remaja. Remaja juga sudah bisa menjalani kepengurusan dengan baik sehingga koordinator hanya perlu memantau saja. Hal tersebut dapat ditunjukkan dari hasil wawancara berikut in:

“...tim posrem dipilih berdasarkan perintah kapus, pembagian tugasnya ya sesuai kompetensi. Timnya lengkap ada bidan, perawat, psikolog, dokter dan semuanya pernah pelatihan PKPR dan konseling..."

Berdasarkan hasil wawancara didapatkan bahwa seluruh tenaga kesehatan yang menjadi tim posyandu remaja telah memiliki kompetensi yang beragam. Tenaga kesehatan tersebut telah mengikuti pelatihan khusus mengenai remaja dan konseling. Hasil wawancara tersebut juga menunjukkan bahwa koordinator posyandu remaja tidak melakukan perencanaan dalam pemenuhan standar tenaga kesehatan. Koordinator hanya menjalankan perintah dari kepala Puskesmas.

Pengetahuan dan kompetensi dapat dicapai dengan membentuk tim PKPR yang memiliki pengetahuan, sikap dan keterampilan dalam melaksanakan pelayanan remaja. Pengetahuan dan kompetensi petugas untuk melaksanakan pelayan remaja dapat dilakukan dengan sosialisasi internal terkait PKPR. Sosialisasi bisa dilakukan dengan transfer knowledge dari petugas yang terlatih PKPR kepada anggota tim lainnya. Memaksimalkan penggunaan pedoman PKPR yang ada untuk 
Tabel 1. Pencapaian SN-PKPR Posyandu Remaja Kota Surabaya

\begin{tabular}{lcccccc}
\hline Nama Posyandu & $\begin{array}{c}\text { Standar } \\
\text { tenaga } \\
\text { kesehatan }\end{array}$ & $\begin{array}{c}\text { Standar } \\
\text { Fasilitas } \\
\text { Kesehatan }\end{array}$ & Standar Remaja & $\begin{array}{c}\text { Standar Jejaring } \\
\text { manajemen } \\
\text { kesehatan }\end{array}$ & $\begin{array}{c}\text { Persentase } \\
(\%)\end{array}$ \\
\hline Posyandu X1 & 31 & 53 & 17 & 10 & 43 & $45 \%$ \\
Posyandu X2 & 32 & 50 & 20 & 6 & 7 & $33 \%$ \\
Posyandu X3 & 56 & 98 & 50 & 0 & 22 & $66 \%$ \\
Posyandu X4 & 57 & 119 & 32 & 0 & 34 & $70 \%$ \\
Posyandu X5 & 35 & 98 & 38 & 6 & 49 & $66 \%$ \\
Posyandu X6 & 56 & 98 & 50 & 0 & 22 & $66 \%$ \\
Posyandu X7 & 45 & 100 & 60 & 8 & 60 & $79 \%$ \\
Posyandu X8 & 36 & 68 & 23 & 1 & 18 & $42 \%$ \\
Posyandu X9 & 39 & 84 & 35 & 5 & 18 & $52 \%$ \\
Posyandu X10 & 45 & 14 & 10 & 1 & 6 & $22 \%$ \\
Posyandu X11 & 29 & 60 & 25 & 12 & 19 & $42 \%$ \\
Posyandu X12 & 24 & 30 & 25 & 10 & 8 & $28 \%$ \\
Posyandu X13 & 51 & 117 & 64 & 12 & 45 & $84 \%$ \\
Posyandu X14 & 60 & 109 & 54 & 8 & 44 & $80 \%$ \\
Posyandu X15 & 60 & 119 & 66 & 16 & 58 & $93 \%$ \\
\hline
\end{tabular}

Sumber: Dinas Kesehatan Kota Surabaya 2015

$\begin{array}{rlr}\text { Keterangan: } & \geq 80 \% & =\text { Paripurna } \\ & 60 \%-79,99 \% & =\text { Optimal } \\ \leq 60 \% & =\text { Minimal }\end{array}$

pelaksanaan PKPR sehingga kegiatan yang dilaksanakan terarah dan terukur.

Pelayanan konseling yang dimaksudkan dalam standar tenaga kesehatan adalah kemampuan tim posyandu remaja dalam melakukan konseling kepada remaja. Kemampuan tersebut meliputi kesanggupan petugas melakukan pelayanan diluar jadwal yang ditetapkan. Kemampuan lainnya adalah kemampuan dalam melatih konselor sebaya agar memiliki kemampuan konseling untuk deteksi dini pada teman sebayanya. Pengetahuan dan kompetensi petugas serta pelayanan konseling yang mumpuni dapat meningkatkan pelayanan kesehatan remaja di posyandu. Hal lain yang secara otomatis dapat tercapai jika keduanya baik adalah standar nasional PKPR sub standar tenaga kesehatan.

Paparan di atas menjelaskan tentang pencapaian untuk standar pertama dalam standar

Nasional pelayanan kesehatan peduli remaja (PKPR) yaitu standar tenaga kesehatan, selanjutnya adalah standar kedua yaitu standar fasilitas kesehatan. Penilaian dalam standar fasilitas kesehatan meliputi paket pelayanan kesehatan serta prosedur, tata laksana dan alur pelayanan. Skor maksimal yang ada adalah 124 poin. Poin pertama yaitu 88 poin untuk paket pelayanan dan 36 poin untuk prosedur, tata laksana dan alur pelayanan (Kemenkes RI, 2013).

posyandu remaja di Kota Surabaya yang memperoleh pencapaian tertinggi pada standar fasilitas kesehatan sebesar $33 \%$ sedangkan $67 \%$ memiliki pencapaian rendah. Persentase tersebut menunjukkan bahwa sebagian besar posyandu remaja di Surabaya memiliki pencapaian minimal untuk standar fasilitas kesehatan.

"...dananya gak cukup mbak, cuma dapat untuk empat kali kegiatan dalam setahun... tempatnya juga gak ada, jadi ya disini nanti ngundang remaja terus penyuluhan gitu..."

Alasan yang dikemukakan tidak dapat dijadikan kendala utama dalam pelayanan, hal ini dapat dibuktikan oleh posyandu remaja lain yang mendapat dana yang sama yaitu untuk empat kal kegiatan. Dana lainnya didapatkan dari hasil usaha mandiri posyandu. Posyandu yang memiliki usaha mandiri bisa menjadi contoh untuk posyandu lainnya dalam hal kemandirian posyandu. Berdasarkan hasil wawancara dapat disimpulkan bahwa posyandu remaja dengan pencapaian minimal hanya memberatkan pelayanan posyandu pada penyuluhan. Sejatinya yang masuk ke dalam paket pelayanan kesehatan remaja bukan sekadar penyuluhan.

Paket pelayanan kesehatan yang masuk penilaian PKPR mencakup berbagai macam pelayanan. Pelayanan tersebut meliputi (a) pencegahan dan penanggulangan anemia dan masalah gizi, (b) tumbuh kembang remaja, (c) kesehatan reproduksi remaja, (d) pencegahan dan penanggulangan masalah kesehatan jiwa, (e) pencegahan dan penanggulangan penyalahgunaan NAPZA, (f) pencegahan dan penanggulangan kekerasan, (g) pencegahan, deteksi dan penanggulangan ISR, IMS, (h) Pencegahan, deteksi dan penanggulangan HIVIAIDS, (i) pencegahan, 
deteksi dan penanggulangan tuberculosis, (j) pencegahan dan penanggulangan cacingan, (k) skrining status TT remaja, (I) pencegahan dan penanganan kehamilan remaja (Kemenkes RI, 2013).

Berdasarkan Kemenkes RI (2013) dalam buku pedoman pelaksanaan pelayanan kesehatan pedul remaja didapatkan bahwa Penilaian yang terdapat dalam prosedur, tata laksana dan alur pelayanan meliputi pelayanan yang mampu mencegah terjadinya missed opportunity, menjamin kerahasiaan, privasi, kenyamanan dan kecepatan. Hal tersebut dapat tercapai jika posyandu remaja memiliki alur tersendir untuk pelayanan remaja. Alur pelayanan remaja terpisah dari alur pelayanan umum, sehingga remaja yang berkepentingan dapat langsung tertangani dan terlayani dengan baik. Selain alur yang harusnya dimiliki adalah ruangan yang dapat menjamin privas remaja. Konseling pada remaja harus dilakukan secara aman dan nyaman serta private. Pelayanan yang dilakukan di dalam gedung baiknya dapat juga dilakukan di luar gedung sehingga remaja memiliki kemudahan dalam mengakses pelayanan kesehatan remaja.

Standar tenaga kesehatan dan fasilitas kesehatan sudah dipaparkan di atas berikutnya adalah standar remaja. Standar remaja merupakan standar ketiga dalam penilaian standar Nasional pelayanan kesehatan peduli remaja. Penilaian dalam standar remaja meliputi penilaian terhadap kegiatan komunikasi, informasi, dan edukasi (KIE) yang dijalankan dan penilaian terhadap konselor sebaya yang dibentuk oleh posyandu remaja. Poin maksimal untuk standar remaja adalah 70 poin, dengan rincian 38 poin untuk indikator kegiatan komunikasi, KIE dan 32 poin untuk indikator konselor sebaya (Kemenkes RI, 2013).

posyandu remaja di Kota Surabaya hanya 20\% yang memiliki pencapaian tertinggi untuk standar remaja sedangkan $80 \%$ memiliki pencapaian rendah. Standar remaja merupakan SN-PKPR yang sulit dicapai bagi sebagian besar posyandu remaja. Hal tersebut disebabkan oleh partisipasi dan antusiasme remaja yang rendah. Menurut koordinator posyandu remaja, jadwal sekolah yang sibuk menjadi salah satu penyebab kurangnya minat remaja atas posyandu. Remaja yang kurang aktif dan kurang partisipatif membuat posyandu sulit dalam membentuk konselor sebaya.

Konselor sebaya merupakan remaja aktif yang telah dilatih untuk melakukan kegiatan konseling bagi teman sebayanya. Hal ini berdasarkan kepada dasar dari kegiatan posyandu remaja dimana remaja merupakan pelopor program kesehatan remaja. Kegiatan dalam posyandu remaja harusnya dirancang dari remaja oleh remaja dan untuk remaja. Remaja yang telah terlatih konselor remaja akan dapat mendeteksi secara dini ketika terdapat permasalahan baik yang dialami sendiri maupun dialami oleh temannya. Kemampuan mendeteksi tersebut membuat remaja mampu melakukan pelaporan dan penyampaian kepada tenaga kesehatan yang ada, sehingga permasalahan bisa segera teratasi (Muthmainnah, 2013).
Menurut Muthmainnah (2013) saat ini peran remaja dalam posyandu hanya sebagai objek. Hal tersebut tentu membuat remaja menjadi pemerhati dan memiliki keterlibatan yang pasif. Kondisi tersebut bisa dijadikan acuan untuk perbaikan kedepannya dimana menjadikan remaja sebagai subjek dalam posyandu remaja. Kondisi tersebut tentu akan membuat remaja merasa memiliki posyandu remaja bukan hanya objek dalam sebuah kegiatan posyandu remaja. Perasaan memiliki tersebut dapat memacu keinginan remaja untuk aktif dalam setiap kegiatan, sehingga memungkinkan untuk dilatih menjadi konselor sebaya.

Kegiatan konselor sebaya selain dilakukan penilaian dari sisi remaja juga dilakukan penilaian dari sisi pendamping. Pendamping dalam hal ini adalah pendamping yang mengelola kegiatan konselor sebaya serta pendamping yang membimbing konselor sebaya. Bimbingan tersebut dilakukan pendamping dalam pelaksanaan konseling bagi kelompok sebaya. Berdasarkan hal tersebut yang telah dipaparkan terkait penilaian tentang standar remaja. Hal paling utama dalam standar ini adalah partisipasi remaja. Semakin tinggi partisipasi remaja otomatis semakin besar kemungkinan sebuah posyandu memiliki konselor remaja yang aktif.

Kesulitan yang tengah dihadapi posyandu remaja dalam memenuhi standar remaja adalah antusias dan partisipasi remaja yang sangat kurang. Posyandu remaja minimal mengungkapkan bahwa remaja dilingkungannya terlalu banyak tuntutan, selain itu orang tua remaja juga tidak mendukung. Hal tersebut ditambah dengan adanya suatu kelompok remaja yang memengaruhi remaja lain untuk tidak ikut kegiatan di Puskesmas seperti kegiatan posyandu remaja. Teknik penjemputan bola juga sudah pernah dilakukan tetapi tetap gagal menarik remaja untuk berpartisipasi aktif di posyandu remaja. Hal tersebut diungkapkan dalam wawancara mendalam sebagaimana terkutip dibawah ini :

“...susah mengumpulkan remaja mbak, orang tuanya juga cuek gak mendukung, karena merasa tidak ada untungnya... Ada kelompok remaja lain yang nyangkruk-nyangkruk itu suka menghadang anak-anak yang mau kesini... ya bagaimana lagi susah memang daerahnya mbak, orang kolot2, sudah jemput bola juga gak berhasil... gimana mau punya konselor sebaya kalau yang ikut posyandu gak tetep ganti2 terus, gak ada yang bisa dipegang..."

Hal tersebut menunjukkan bahwa remaja adalah pemeran utama dalam posyandu, khususnya dalam penilaian indikator konselor sebaya. Bilamana posyandu remaja belum memiliki anggota remaja yang aktif dan partisipatif maka tidak ada kemungkinan posyandu remaja tersebut membentuk dan melatih konselor sebaya. Berlaku sebaliknya jika posyandu remaja memiliki anggota remaja yang aktif dengan partisipasi yang tinggi besar kemungkinan untuk membentuk konselor sebaya. Konselor sebaya yang aktif ini yang nantinya akan dapat menunjang 
kemandirian posyandu remaja. Konselor sebaya tersebut juga output-nya akan memiliki kemampuan untuk melakukan kegiatan komunikasi, memberikan KIE terhadap teman sebayanya.

Kegiatan KIE masuk dalam indikator penilaian standar remaja. Penilaian indikator KIE meliputi pengetahuan, keterampilan dan sikap petugas tentang masalah kesehatan remaja. Hal tersebut berkaitan tentang materi yang diberikan kepada remaja dalam kegiatan KIE. Materi tersebut meliputi materi tentang tumbuh kembang remaja, bahaya perilaku seksual berisiko, bahaya penyalahgunaan NAPZA (termasuk rokok dan alkohol), Infeksi saluran reproduksi, penyakit menular seksual, HIVIAIDS, serta akibat pernikahan dini dan kehamilan tak dikehendaki. Kemampuan remaja dalam melakukan komunikasi, informasi, dan edukasi juga masuk ke dalam penilaian (Kemenkes RI, 2013).

Standar keempat setelah standar tenaga, standar fasilitas dan standar remaja adalah standar jejaring. Penilaian dalam standar jejaring meliputi pemetaan mitra dan partisipasi remaja. Pemetaan mitra yang dimaksudkan adalah pemetaan pemangku kepentingan dan pegiat dalam bidang kesehatan remaja. Sedangkan partisipasi remaja meliputi keterlibatan remaja dalam merencanakan, melaksanakan, dan mengevaluasi kegiatan PKPR. Poin maksimal untuk penilaian standar jejaring adalah 18 poin, dengan 6 poin untuk indikator pemetaan remaja dan 12 poin untuk indikator partisipasi remaja (Kemenkes RI, 2013).

Pencapaian posyandu remaja di Kota Surabaya untuk standar jejaring dengan pencapaian rendah untuk standar jejaring lebih banyak yaitu 93\%. Sebagian besar posyandu remaja di Kota Surabaya belum memiliki jejaring.

Jejaring merupakan mitra kerjasama yang dalam hal ini mampu menunjang pelaksanaan posyandu remaja. Kontribusi jejaring bisa berupa materi, tempat atau tenaga. Tenaga disini yang dimaksudkan adalah tenaga yang dapat membantu dalam pelaksanaan posyandu remaja. Hal ini bisa didapat dengan mengadakan kerjasama lintas sektor maupun lintas program. Misalkan bekerjasama dengan badan narkotika Nasional (BNN) terkait kegiatan penyalahgunaan narkoba. Contoh lain adalah bekerjasama dengan program UKS terkait kegiatan imunisasi TT. Kerjasama lain lintas sektor seperti dengan kelurahan terkait perijinan tempat atau pos dan lain sebagainya. Kerjasama terkait materi bisa didapatkan dengan cara melakukan sponsorship saat ada kegiatan di posyandu remaja. Berbagai hal bisa dilakukan untuk memenuhi standar jejaring dalam posyandu remaja.

SN-PKPR kelima adalah standar manajemen kesehatan yang meliputi indikator advokasi, pencatatan dan pelaporan, supervisi, pemantauan dan penilaian, serta sistem rujukan. Poin maksimal untuk standar manajemen kesehatan adalah 70 poin dengan rincian sebagai berikut 16 poin untuk indikator advokasi, 11 poin untuk indikator pencatatan dan pelaporan, 18 poin untuk indikator supervisi, dan 25 poin untuk indikator sistem rujukan (Kemenkes RI, 2013).
Pencapaian tertinggi pada standar manajemen kesehatan hanya $13 \%$ dari posyandu remaja di Kota Surabaya. Posyandu remaja dengan pencapaian minimal lebih banyak yaitu $87 \%$. Penilaian dalam variabel advokasi meliputi pelaksanaan advokasi ke berbagai pemangku kepentingan baik lintas sektor maupun lintas program. Kedua kepentingan tersebut membutuhkan dalam pelaksanaan program posyandu remaja. Berdasarkan pelaksanaan advokasi tersebut dinilai apakah ada komitmen yang terbentuk setelahnya misalnya, komitmen dalam penyediaan tenaga, bantuan teknis, dana, prasarana dan sarana, obat-obatan, jadwal pelaksanaan dan lain sebagainya. Posyandu remaja dalam melaksanakan advokasi tersebut apakah memiliki dokumen yang dapat mendukung kegiatan serta melibatkan remaja dalam kegiatan advokasi. Semuanya masuk ke dalam penilaian SN-PKPR.

Penilaian variabel pencatatan dan pelaporan meliputi apakah remaja dilibatkan atau tidak. Hal lain yang dinilai dalam pencatatan dan pelaporan adalah adanya pedoman terkait pencatatan dan pelaporan. Pedoman tersebut selalu digunakan dalam melakukan pencatatan dan pelaporan. Berdasarkan pada pedoman tersebut posyandu memiliki format pencatatan dan pelaporan yang kedepannya bisa dijadikan acuan dalam melakukan pencatatan dan pelaporan. Hasil yang didapatkan dari kegiatan pencatatan dan pelaporan tersebut kemudian apakah dilaporkan ke jenjang yang lebih tinggi. Berbagai ha tersebut menjadi penilaian dalam standar manajemen kesehatan.

Supervisi, pemantauan dan penilaian juga masuk dalam standar manajemen kesehatan. Kegiatan tersebut terdiri dari evaluasi diri yang dilakukan oleh posyandu remaja, pemantauan akan pelaksanaan kegiatan yang ada, serta penilaian atas pelaksanaan kegiatan yang ada. Evaluasi dir yang dilakukan oleh posyandu remaja dilakukan berdasarkan instrumen supervisi fasilitatif program PKPR. Hasil dari evaluasi digunakan untuk tindak lanjut dan perbaikan kedepannya.

Evaluasi diri yang dilakukan oleh posyandu remaja diimbangi dengan pemantauan pencapaian standar Nasional PKPR oleh posyandu remaja. Sehingga posyandu remaja dapat memacu diri untuk memenuhi standar Nasional yang ada. Selain itu terdapat penilaian tahunan SN-PKPR. Penilaian tahunan tersebut dimaksudkan untuk evaluasi dan mendapatkan umpan balik serta bahan untuk melakukan perencanaan berikutnya. Remaja disertakan dalam kegiatan ini diharapkan terdapat dua arah pemantauan dan evaluasi, sehingga penilaian tidak hanya dari satu sisi petugas. Aspirasi dari remaja justru lebih diperlukan karena posyandu remaja adalah kegiatan yang dilakukan dari remaja, oleh remaja dan untuk remaja.

Penilaian selanjutnya untuk manajemen kesehatan dalam posyandu remaja adalah sistem rujukan. Sistem rujukan memiliki penilaian lebih tinggi dibanding tiga variabel lainnya dimana poin maksimal untuk penilaian sistem rujukan adalah 25 poin dengan maksimal total poin untuk standar manajemen kesehatan adalah 70 . Sistem rujukan 
dalam posyandu remaja meliputi tiga sistem rujukan yaitu rujukan medik, rujukan hukum, dan rujukan sosial.

Rujukan medik merupakan upaya rujukan yang bersifat kuratif. Rujukan medik digunakan jika remaja dirasa perlu mendapatkan pengobatan lebih lanjut terkait masalah yang dihadapi. Rujukan medik berkaitan dengan kondisi kesehatan baik fisik maupun psikis. Masalah kesehatan fisik seperti penyakit yang tengah dialami oleh remaja pada fisik tubuhnya. Sedangkan masalah kesehatan psikis pada remaja berkaitan dengan kesehatan jiwa remaja, dimana kondisi ini lebih memerlukan perhatian khusus dikarenakan tidak terlihat sebagaimana pada masalah kesehatan fisik.

Rujukan hukum merupakan upaya rujukan yang dilakukan dalam perihal hukum. Dimana jika remaja bermasalah dengan hukum. Remaja yang bermasalah dengan hukum tersebut bisa dalam bentuk kenakalan remaja ataupun ketidaksengajaan. Jika remaja mendapatkan masalah terkait hukum maka posyandu remaja melakukan rujukan hukum ke pihak yang berwenang dan berkompeten dalam menangani masalah hukum remaja.

Rujukan Sosial merupakan pelayanan bag remaja yang mempunyai masalah sosial. Misalnya remaja yang memiliki masalah dalam hal administrasi kependudukan, keterangan domisili dan akte kelahiran. Jika remaja membutuhkan pengurusan surat keterangan bagi remaja yang miskin dapat diselesaikan dengan rujukan sosial. Rujukan sosial tersebut mengacu pada pihak yang bisa membantu remaja yang bermasalah untuk mengakses berbagai sumber sosial yang dibutuhkan.

\section{SIMPULAN}

posyandu remaja di Kota Surabaya bertempat di 15 Puskesmas yang telah dinobatkan sebagai Puskesmas pelayanan kesehatan peduli remaja (PKPR). Posyandu remaja tersebut memiliki tantangan dan karakter yang berbeda satu sama lain. Posyandu remaja yang tersebar di 15 Puskesmas, belum semuanya mencapai penilaian paripurna, diantaranya masih optimal bahkan ada yang minimal. Penilaian tersebut berdasarkan pada standar nasional pelayanan kesehatan peduli remaja.

Berdasarkan hasil penelitian, tingkat Pemenuhan standar nasional Pelayanan Kesehatan Peduli Remaja (PKPR) Kota Surabaya rata-rata sudah mencapai standar PKPR tersebut. Sesuai indikator dari standar PKPR tersebut, hal ini terbagi menjadi tiga kategori posyandu remaja, yaitu posyandu dengan kategori paripurna, posyandu dengan kategori optimal dan posyandu dengan kategori minimal. Posyandu remaja yang mendapatkan kategori paripurna adalah $26 \%$. Posyandu remaja yang mendapatkan kategori optimal adalah 33\%. Posyandu remaja yang memiliki kategori minimal adalah $41 \%$. Rekomendasi yang bisa diberikan dari penelitian ini adalah posyandu dengan pencapaian minimal bisa mengambil pelajaran dari posyandu dengan pencapaian tertinggi. Mengadopsi tips dan trik yang dilakukan posyandu remaja paripurna maupun optimal dalam melaksanakan kegiatan posyandu remaja. Selain itu juga mengadopsi tips dan trik dari posyandu remaja dengan kategori paripurna dalam memenuhi standar PKPR.

Posyandu remaja dalam melakukan penilaian dan evaluasi hendaknya menggunakan pedoman yang khusus ditujukan untuk posyandu remaja sehingga penilaian terfokus di pelayanan posyandu remaja. Sekarang belum terdapat pedoman khusus yang ditujukan untuk pelaksanaan posyandu remaja. Sekarang penilaian untuk posyandu masih berdasarkan kepada pedoman PKPR dimana penilaian didalamnya tidak fokus untuk posyandu remaja melainkan program PKPR. Posyandu remaja sejatinya adalah bagian dari kegiatan program PKPR yang luar gedung, sedangkan penilaian yang terdapat dipedoman yang ada mencakup keseluruhan program PKPR. Hal tersebut tentu tidak efisien dan tidak objektif untuk penilaian posyandu remaja, jika posyandu remaja dinilai berdasarkan standar pelayanan PKPR.

\section{DAFTAR PUSTAKA}

Departemen Kesehatan RI. 2006. Pedoman Umum Pengelolaan Posyandu. Jakarta: Departemen Kesehatan RI.

Dinas Kesehatan Kota Surabaya. 2012. Profil Kesehatan Kota Surabaya. Surabaya: Dinas Kesehatan Kota Surabaya.

Herland. 2004. Laporan Akhir Pengembangan Jejaring Pelayanan Kesehatan Peduli Remaja (PKPR) dan Rujukannya di Tingkat Kabupaten di Provinsi Jawa Tengah dan Jawa Timur, Laporan Konsultan Proyek SMPFA, Jakarta: Depkes RI.

Kementerian Kesehatan RI. 2004. Kebijakan Dasar Pusat Kesehatan Masyarakat. Jakarta: Kementerian Kesehatan RI.

Kementerian Kesehatan RI. 2013. Pedoman Standar Nasional Pelayanan Kesehatan Peduli Remaja $(P K P R)$. Jakarta: Kementerian Kesehatan RI.

Muadz, M. 2008. Panduan Pengelolaan Pusat Infromasi dan Konseling Kesehatan Reproduksi Remaja. 2 penyunt. Jakarta: Badan Koordinasi Keluarga Berencana Nasional.

Muthmainnah. 2013. Analisis Stakeholder Remaja terhadap Implementasi Program Pelayanan Kesehatan Peduli Remaja (PKPR) di Kota Semarang. Promosi kesehatan, Volume I, pp. 170-183.

Ningsih. 2017. Analisis pelaksanaan fungsi manajemen POAC dengan pencapaian SN-PKPR pada posyandu Remaja di Kota Surabaya. Dalam: Skripsi. Surabaya: Fakultas Kesehatan Masyarakat Universitas Airlangga.

Romauli, V.S. 2011. Kesehatan Reproduksi buat Mahasiswi Kebidanan. Yogyakarta: Penerbit Muha Medika.

SDKI. 2012. Survei Demografi dan Kesehatan Indonesia. Jakarta: SDKI.

Undang-Undang RI. 2009. Kesehatan, Jakarta: Kementerian Kesehatan RI. 